\title{
Day Times Picomole Per Liter Per Kilogram
}

National Cancer Institute

\section{Source}

National Cancer Institute. Day Times Picomole Per Liter Per Kilogram. NCI Thesaurus.

Code C112265.

Days times picomoles per liter, divided by kilograms. 